\title{
Accountability in the Internet Era: A Lesson from Local Governments in Indonesia
}

\author{
Habib Muhammad Shahib, Firman Rato Risky \\ School of Accounting, University of Brawijaya, Malang, Indonesia
}

\begin{abstract}
Nowadays, Indonesia is one of the countries with the highest internet user growth. In line with it, the local governments in Indonesia use their official website to report the government's activities as an accountability form to the society. Thus, this study conducted for knowing the accountability characteristics and the factors that affect the level of internet accountability reports in the local government websites.

Using content analysis based on Global Reporting Initiative (GRI) index in government agencies and OLS statistical approach on the 34 provinces' official websites, this study finds, in general, the provinces' websites have reported $63 \%$ of the total numbers that suggested by GRI. Furthermore, there are two main factors, i.e. the number of population and districts/cities, which positively affect the level of accountability reports in provinces' website. However, no empirical evidence shows the press pressure affects the broad of website reporting in the Indonesia provinces context.

Overall, this research indicates that the Indonesia local governments, in this case, provincial governments have focused on delivering their accountability to the society. Moreover, this is a good sign for the democracy growth in Indonesia. Furthermore, the Indonesia local governments may have to give more portions on their official website for answering the headline news from the mass media, specifically for the environmental and social themes. Therefore, it will further strengthen the governancesustainability and democracy in Indonesia local government environment.
\end{abstract}

Keywords: Accountability, website, local government, democracy, Indonesia

*Corresponding author's email: muh.shahib@unifa.ac.id ISSN: 2549-3221 (Print) 2549-323X (Online)

DOI: http://doi.org/10.26487/hebr.v111.940 


\section{Introduction}

After the 1998 reform movement, Indonesia has changed significantly in politics and economic aspects where political power distributed to all provinces, districts (Kabupaten), and cities (Kota). In Indonesia term, it is well known as otonomi daerah (regional autonomy). This situation makes thelocal government more powerful to givea policy in its region, especially, the economic policy (Sanusi, Butler, \& Rola-Rubzen, 2013). Hence, the local government can easily invite the investor to invest in its area in many sectors, particularly in natural resource sectors such as forestry, plantation, marine, and mining which always become the main industries that support Indonesia's economic (WALHI, 2015). As consequences of this change, many local and International investors directly invest and build industries in local natural resource sectors that lead to the increasing value of the corporation, local government revenue and job opportunities for local Indonesian people (World-Bank, 2012).

In line with the 1998 reformation spirit and the local economic growth, the local governments ofIndonesia alsovoluntarily try to be more accountable to their people. Several kinds of accountability commonly used by the local governments in Indonesia. For instance; making an annual report, publish an advertorial in the local newspapers. Also, the popular one in nowadays, developing the official websites as an easy and a cheap way to deliver the government's accountability information broadly. Especially, since, Indonesia becomes one of the countries with the highest number of internet users in the world (Internet World Stats, 2016).

However, the local economic growth also has the worse sides that lead to the several adverse effects. For example; natural resources conflict happened, many local people banished from their cultivated fields (LBH, 2016; WALHI, 2015). The ecological disaster also occurs such as forest fires, water and local food scarcity and local ecosystems destruction (WALHI, 2015; World Resources Institute, 2015). Consequently, many people and environmental-social activists protest and doubt to the development of social and environmental accountability in the local context. Because, the local governments are seen less transparent and participative in their accountability practices (LBH, 2016; Republika Online, 2015; WALHI, 2015). Specifically, it can be seen from the local government's comprehensive social-environmental accountability report that is still difficult to find (LBH, 2016; WALHI, 2015). Even though, the local governments already have an official website and using it as an accountability tool to report their performance voluntary.

Furthermore, in line with the contradiction in seeing the accountability practice in this internet era between the local government and the socioenvironmental activist. The earlier researchers had explained that several things might affect the accountability practices in government bodies in this website accountability era. For instance: political pressure, public media visibility, access to information technology and people educational level (Amanda Ball, 2005; Bertot, Jaeger, \& Grimes, 2012; Gandı'a \& Archidona, 2008). Unfortunately, the previous researchers tend tofocus on thefinancialand economic accountability issues (Bertot et al., 2012; Gandı'a \& Archidona, 2008; Guillamón, Bastida, \& Benito, 2011; Pina, Torres, \& Royo, 2009; Torres, Pina, \& Royo, 2005) than try to examine the accountability in environmental and social issues (TiradoValencia, Rodero-Cosano, Ruiz-Lozano, \& Rios-Berjillos, 2016). Specifically, in 
developing country context (Joseph, Pilcher, \& Taplin, 2014) that always face the wider social-environmental problems. Moreover, research on environmental and social report issues based on internet reporting is also still dominated by the voluntary reporting perspective (Joseph et al., 2014; TiradoValencia et al., 2016) because the internet report standard in government bodies still does not exist (Greiling, Traxler, \& Stötzer, 2015; Tirado-Valencia et al., 2016). For these reasons, it recommends doing more studies to examine the more broadly internet accountability report in particular circumstances. Especially, in the local government in developing countries that always face the environmental and social issues such as Indonesia's local governments ( $\mathrm{LBH}$, 2016; Republika Online, 2015; WALHI, 2015; World Resources Institute, 2015).

On that basis, this study seeks to examine and add empirical evidence about the more broadly internet-based accountability practices in the context of the local governments in Indonesia. By examining the social, environmental, economic issues together and identifying the determinant factors that affect the accountability practices in the Indonesia provincial governments' official website. So the central research questions are:

RQ1: What are the characteristics of Internet-based accountability in Indonesia's provincial government context?

RQ2: Do the different provincial characteristics affect the level of accountability report in the provincial governments' official websites?

This research gives several contributions. First, in developing the accounting and accountability literature. Specifically, in the websitebased accountability context in the local governments in the developing country.
Second, giving the policy inputs to the local governments in developing their accountability style in sustainability issues, and third, giving positive inputs to environmental and social activists in communicating their demand that related to the social and environmental issues. Moreover, this paper discussed in a structured path. First, introduction, second, literature review and hypothesis development, third, research design, fourth, result and discussion, and the last, conclusion.

\section{Literature Review}

Accountability reports as the form of social legitimacy

In accounting and accountability literature, the accountability reports such as financial statement and annual report believed as the symbol of social legitimacy in society's daily life. It based on legitimacy theory perspective (C. G. Deegan, 2007; Gray, Kouhy, \& Lavers, 1995; Guthrie \& Parker, 1989; Lanis \& Richardson, 2013; O’Donovan, 1999, 2002). Legitimacy theory explains that organizations always try to act in a responsible manner in the front of society for keeping their existence and legitimacy (C. Deegan, Rankin, \& Tobin, 2002; O'Donovan, 2002). But, the responsible acts are not enough, the organizations should communicate their good activities to the external parties thus the society will know and support the organizations' existence. In this point, financial statement and annual report become the main tools to maintain organizations' existence. Because, they are accessible to the public (C. G. Deegan, 2007). For examples; financial statement to inform the financial activities of the organizations such as assets, liability, revenue, salary expense, and specifically tax as a symbol of organizations' social awareness (Lanis 
\& Richardson, 2013), and annual report as a tool to inform others dimension in organizations' activities. For instance, strategic management of an organization, supervision acts of the board of director, and corporate social responsibility (C. Deegan et al., 2002; C. G. Deegan, 2007; Gray et al., 1995; Lanis \& Richardson, 2013; Wilmshurst \& Frost, 2000).

Furthermore, as a social legitimacy form, the reports specifically shaped by social-community characteristics. Starting from the concern of society, for example, in earlier 90s, the United Nations, World Bank, International Labour Organization broadly promoted and pushed their recognized guidelines for the corporate responsibility acts across the world and become a reference for organizations in making their reports (Moura $\square$ Leite \& Padgett, 2011; Waddock, 2008). Until using the reports as a tool to divert public focus from the social-environmental problems that faced by organizations. For instance, several organizations that face social and environmental challenges. Such as spilling crude oil into the sea (Patten, 1992), impeached by the environmental bodies (C. Deegan \& Gordon, 1996), pushed by the medias' reports (Brown \& Deegan, 1998), till did tax evasion (Lanis \& Richardson, 2013). They tend to publish their corporate responsibility disclosure broader in the annual report to maintain their legitimacy image in front of the society.

Unfortunately, the researchers that examined the reports as a legitimacy form are still dominated by corporate perspective and based on physical reporting (Brown \& Deegan, 1998; C. Deegan \& Gordon, 1996; C. Deegan et al., 2002; C. G. Deegan, 2007; Gamerschlag, Moller, \& Verbeeten, 2010; Lanis \& Richardson, 2013; O’Donovan, 1999, 2002; Patten, 1992; Shahib \& Irwandi, 2016; Wilmshurst \& Frost, 2000).
Whereas, on the other hand, there are still limited studies that examine another perspective such as government perspective (Carol A. Adams, Muir, \& Hoque, 2014; Greiling et al., 2015; Qian, Burritt, \& Monroe, 2011; Williams, Wilmshurst, \& Clift, 2011). Specifically in using internet reporting as a tool to report the government activity in this internet era (Bertot et al., 2012; Gandı'a \& Archidona, 2008; Tirado-Valencia et al., 2016).

\section{Internet-based Accountability Disclosure}

Accountability disclosure based on the website has commonly known by the private companies, and it has evaluated by many kinds of literature (Carol A Adams \& Frost, 2006; Bolívar, 2007; Jose \& Lee, 2007; Lodhia, 2006). Based on the arguments that, there are several advantages in using a website as an accountability form. Such as; the companies easily to connect, communicate with their stakeholders and also the companies can maintain their image in the front of stakeholder and society as cheaper as possible (Pollach, Scharl, \& Gill, 2005).

In line with previous statements, based on the new public management (NPM) perspective (Cheung, 2011; Osborne \& Gaebler, 1992). Many of the local governments around the world try to use the website as an accountability tool for gaining the same advantages as well as the private firms (Coupland, 2006; Pilcher, 2011). However, in the government and public field, there are still limited studies that have examined the accountability disclosure theme (Gandı'a \& Archidona, 2008; Greiling et al., 2015; Joseph et al., 2014; TiradoValencia et al., 2016). And the literature just tend to focus on financial and economic accountability issues in the developed countries' local governments 
(Bertot et al., 2012; Gandı' a \& Archidona, 2008; Guillamón et al., 2011; Pina et al., 2009; Torres et al., 2005) then trying to examine the accountability issues more broader such as including the social and environmental issues (TiradoValencia et al., 2016). Especially, in developing country setting that always face the wider economic, social, and environmental problems (Joseph et al., 2014). Therefore, this paper adds a new insight into the literature of internet accountability reporting. Specifically, in the local government of a developing country.

\section{Internet-based Accountability in The Local Governments}

Several pieces of research examined the web-based accountability issue in the local governments (Gandı' a \& Archidona, 2008; Greiling et al., 2015; Joseph et al., 2014; Tirado-Valencia et al., 2016). And the researchers found, nowadays the local government has begun to more focus in more wider accountability issues as in the environmental and social issues (Greiling et al., 2015; Joseph et al., 2014; Tirado-Valencia et al., 2016). Moreover, several similarities found by previous studies as the determinant factors which affect the broader accountability report in the local government's websites. For instance, size and the modern status of the local area (Greiling et al., 2015; Joseph et al., 2014), government's political strategy (Joseph et al., 2014; Tirado-Valencia et al., 2016) and political pressure (Gandı'a \& Archidona, 2008; TiradoValencia et al., 2016). In addition, public media visibility, access to information technology and people educational level are also other determinant factors that affect the disclosure level in the local governments' official websites (Amanda Ball, 2005; Bertot et al., 2012; Gandı' a \& Archidona, 2008).

However, the previous studies tend to focus on examining the website-based reporting in developed countries, for instance, Gandı'a and Archidona (2008) in Spain, Greiling et al. (2015) in Austria, Germany, and Switzerland and TiradoValencia et al. (2016) in several big cities in Europe. On the other hand, there are still limited previous studies that focus on the developing country context. At the time of this research, as a representative of the developing countries, only Joseph et al. (2014) that studying the local government's web-based accountability reporting in Malaysia.

Furthermore, as the former scholars examining the level of internet disclosure based on the voluntary perspective (Gandı'a \& Archidona, 2008; Greiling et al., 2015; Joseph et al., 2014; TiradoValencia et al., 2016). Thus, they developed or adopted the accepted standard such as Global Reporting Initiative (GRI) standard in finishing studies. This study also takes the GRI reporting in government agencies standard (GRI, 2010) for examining the level of accountability in the provincial governments' official website and also in harmony with adding a new insight to the literature related to the internetbased accountability issues in the local government and the developing country situation.

\section{Hypothesis Development}

Based on the second research question and the literature review in previous sections, several hypotheses have developed in this chapter concerning the causes expected to affect Indonesia provincial authorities' webbased accountability disclosure level. Furthermore, in harmony with the view of accountability reports as the form of social legitimacy (C. G. Deegan, 2007; Gray et al., 1995; Guthrie \& Parker, 1989; Lanis \& Richardson, 2013; 
O'Donovan, 1999, 2002). This study focuses on those that are most related and believed as the explanations of social legitimacy in the website environment and the accountability level on provincial governments' official websites.

\section{The number of people and districts}

The key of social legitimacy of a government based on the people support (Dowling \& Pfeffer, 1975; Tyler, 2006). Higher the people number linked to the authorities more pushed the authorities to be accountable, as a consequence of the democracy logic and the governments need to maintain their image (Light, 2011; Lipsky \& Smith, 1989). Moreover, it leads to the governments extent their accountability disclosure in the annual reports (Rosair \& Taylor, 2000) and website (Groff \& Pitman, 2004; Joseph et al., 2014). For ensuring the society can access and believe to the government's management and governance, and at the end the social legitimacy of government maintained (Morison, 2000; Newman, 2001; Pierre, 2000; Rothstein, 2011).

Moreover, higher the people number of one area, it leads to the development of the new city or district (Coale \& Hoover, 2015; Kundu, 2011). As happened in Indonesia, as time goes on, many new districts and cities created in several provinces (BPS, 2015) in line with the growing of population in the provinces. Consequently, these situations push the provincial authorities to be more accountable as higher the number of people and districts/cities that the provincial government leads. Thus, the first hypothesis developed as follows:

H1a: the people number in the provincial area positively affects to the amount of accountability disclosure in the provincial official websites.

$H 1 b$ : the number of the district in the provincial area positively affects to the amount of accountability disclosure in the provincial official websites.

\section{The number of press news}

The public media is one of democracy pillars (Waisbord, 2013) as they play a significant role in maintaining the democracy with their news that becomes a symbol of the people voice (Conrad, 1997; Olausson, 2010). As a symbol of the people voice, the medias with their news tend to represent the people needs in criticizing and appreciating the government activities (Norris, 2006). So, the mass media is also one factor that affects social legitimacy of the governments (Cappella \& Jamieson, 1997; Graber, 2009). Furthermore, Mass medias with the broad range of their news, specifically in this internet era become more powerful to oversee and criticize the governments. Thus, the governments always try to act in a responsible manner for keeping their good image in the front of mass media as well as they hope can also maintain their image in the society (Graber, 2009; Herman \& Chomsky, 2010). And making broader the government's accountability disclosure in the annual report and the official website are the main options to counterbalance the mass media news (Gandı'a \& Archidona, 2008; Joseph et al., 2014). Therefore, the second hypothesis developed as follow:

H2: the high quantity of press news positively affects to the number of accountability disclosure in the provincial official websites.

\section{The economic potency}

It has been believed that the economic growth of the local governments in Indonesia based on the economic potency 
of each region (Sanusi et al., 2013; World-Bank, 2012). Starting from the agriculture, forestry, plantation, fishery, energy, mining, tourism, until to the small, medium, creative (SMC) potency (BI, 2015; World-Bank, 2012). However, in line with the rising of economic and industry in local regions in Indonesia. Nowadays, several worse effects of the economic growth happened in Indonesia local regions. Such as many local people banished from their cultivated fields (LBH, 2016; WALHI, 2015), the forest fires, water and local food scarcity and local ecosystems destructions also happened that lead to the ecological disaster (WALHI, 2015; World Resources Institute, 2015). Therefore, the sustainability of the local governments' social legitimacy threatened.

The previous socio-legitimacy literatures have warned these situations above. The organizations that face many or hard social legitimacy threats can disclose more positive information on their accountability tools. Starting from making the good advertisements in the mass media, until disclosing more good information in the organisations' annual report and the official websites for distracting the society views (Brown \& Deegan, 1998; C. Deegan \& Gordon, 1996; Gandı'a \& Archidona, 2008; Joseph et al., 2014; Patten, 1992; Tirado-Valencia et al., 2016). These approaches believed can maintain the social legitimacy of organization in the society. Thus, the third hypothesis developed as follows:

$\mathrm{H}_{3}$ : the high quantity of the economic potency positively affects to the number of accountability disclosure in the provincial official websites.

\section{The revenue of provincial governments}

It argued that the organizations with the high revenue tend to be accountable than organizations with the small revenue. Based on the view, by having more revenue, the organizations have more funds for doing accountability activities (Christiaens, 1999; Laswad, Fisher, \& Oyelere, 2005). Also, it widely believed that the organizations do not want a revenue decreasing. So, the organizations do more accountability activities for ensuring their image in the front of society well maintained as well as their income increasing (Brown \& Deegan, 1998; C. Deegan \& Gordon, 1996; Lanis \& Richardson, 2013; Patten, 1992). Furthermore, even the previous literature tends to focus on the private sector. The new public management view believes that the same situations also happened in the public sector (Cheung, 2011). Especially, in this internet era, where the public awareness in the local governments' financial accountability is increasing (Gandı'a \& Archidona, 2008; Joseph et al., 2014; Tirado-Valencia et al., 2016). Hence, the fourth hypothesis developed as follows:

H4: the high amount of the revenue of provincial governments positively affect to the number of accountability disclosure in the provincial official websites.

\section{The number of universities}

The technology and internet literacy in the society believed as one factor that making people can easily access the news and criticize the governments. Even, threating the social legitimacy of governments (Eltantawy \& Wiest, 2011; Enikolopov, Petrova, \& Zhuravskaya, 2011). In fact, several studies found the internet literacy based on the people education quality (Buckingham, 2007; Eshet-Alkalai, 2004; Livingstone, 2004). Specifically, for individuals who have accessed the university education level (Metzger, Flanagin, \& Zwarun, 2003). 
Thus, higher the university number in one region will lead to the people's internet literacy and also can help people to access the local governments' official website for suggesting or criticizing the local governments. Thus, the local governments will maintain their image by using a broader disclosure in their official websites for preventing the loss of social legitimacy in this internet era (Gandi'a \& Archidona, 2008). Finally, the fifth hypothesis is:

$\mathrm{H}_{5}$ : the high number of the universities positively affect to the number of accountability disclosure in the provincial official websites.

\section{Research Design}

The whole website of 34 Indonesia provinces governments were studied for their accountability level. To add the reliability and validity, all websites were examined during November 2016 as the websitecontentalways changesfrequently (Gandı'a \& Archidona, 2008; Joseph et al., 2014; Purushothaman, Hancock, Brown, \& Scharl, 2006). Moreover, even though, the use of websites in the local government has become a common thing in the world. The standard for presenting the accountability disclosure on the internet does not exist. The previous studies just used self-developed metrics or re-developed metrics from other studies for evaluating the level of accountability on the government website (Gandı' a \& Archidona, 2008; Greiling et al., 2015; Joseph et al., 2014; Tirado-Valencia et al., 2016). However, in 2010, the Global Reporting Initiative (GRI), as a non-profit organisations that concern in developing and publishing the guidelines for reporting on economic, environmental, and social performance, has published a guideline that called "GRI Reporting in Government Agencies" for examining the accountability in government agencies (GRI, 2010). So this study used GRI guidelines in government agencies as a standard for answering the first research question and examining the level of accountability in the provincial government's official website in Indonesia as the dependent variable in this research. 15 disclosure items divided into five main indicators as the standards. As show in Table I, this research used content analysis, if a provincial website disclosed one item, it was given a score of one, if not zero. And the percentage of website accountability level (PWAL) was calculated as follows:

Table 1

GRI in Government Agencies Score

\begin{tabular}{lc}
\hline & Mean \\
Organizational Profile & 1 \\
PA1. Depict the relationship to other governments and the position of the agency within the govern- \\
mental structures. & 1 \\
Public Policies and Implementation Measures & 3 \\
PA2.Depict sustainable development used by the government, and any principles implemented to & 0 \\
guide sustainable development polices. & \\
PA3. Depict the aspects for which the organization has recognized sustainable development policies. & 1 \\
PA4. Illustrate the specific goals of the organization for the each aspects in sustainable development & 1 \\
policies . & 1 \\
PA5.Depict the procedure by which the parts and goals in both PA3 and PA4. & 1
\end{tabular}


PA6. Provide the following information:

Implementation measures; Results of effectivity relevant

assessments of the measures; Government targets and key indicators used to assess the progress of outcome; Description of progress about goals and targets including results of main indicators; Activities to continuously improve the public authorities' goals and targets; and Post operation audit and targets for next period.

PA7. Illustrate the role of and engagement with stakeholders with respect to the items disclosed in PA6.

Expenditures

PA8. Depict Gross expenditures broken down by type of payment.

PA9. Depict Gross expenditures broken down by financial classification.

PA10. Depict Capital expenditures by financial classification.

PA11. Illustrate procurement policy of the public agency as relates to sustainable development.

PA12. illustrate economic, environmental, and social criteria that put on to expenditures and financial commitments.

PA13. Illustrate linkages between the government's procurement practices and its public policy main concern

PA14. Depict the total value or percentage of items purchased that were listed with voluntary environmental or social labels and/or certification programs, broken down by type.

PA15. Depict the outcomes of assessments of the efficiency and effectiveness of services provided by the government, including the actions engaged to achieve improvements in the future.

The overall score of accountability level from 34 provincials' official websites

Moreover, the independent variables in this research were developed based on the previous studies that concern on website and accountability issues that based on the social legitimacy view (Gandı'a \& Archidona, 2008; Greiling et al., 2015; Joseph et al., 2014; TiradoValencia et al., 2016). They included the number of people (NP) and districts (ND), the number of media news (MN), economic potency (EP), revenue of provincial governments (RP), and the number of universities (NU) in the provincial region. Data for these independent variables gathered from the centre of statistic Indonesia (Badan Pusat Statistik)(BPS, 2015), Bank of Indonesia (BI, 2015), the centre of high-education of Indonesia (Forlap-
DIKTI)(DIKTI, 2016) as for counting the number of universities. And from the "google.com" as for calculating the press news quantity in years range 2015 to 2016 (Gandı'a \& Archidona, 2008). In addition, for answering the second research question, this study also used a statistical approach for reducing the data skewness by using logarithm natural (LN) (Ghozali, 2005) for all independent variables. Except, the economic potency variable as it was measured by counting many provincial potencies. If a provincial has one item of the AFP (agriculture, forestry, plantation), fishery (F), energy and mining (EM), tourism (T) potency, until to the small, medium, creative (SMC) potency. The provincial was given a score of one, if not zero, with the range 
Table 2

Descriptive Statistics

\begin{tabular}{|c|c|c|c|c|c|}
\hline & $\mathrm{N}$ & Min & $\operatorname{Max}$ & Mean & Std. Dev \\
\hline Number of people & 34 & 595,000 & $46,709,600$ & $7,519,985.294$ & $10,793,709.635$ \\
\hline Number of districts/cities & 34 & 5 & 39 & 15.117 & 8.967 \\
\hline Number of news & 34 & 204 & 300 & 273.529 & 23.700 \\
\hline Economic Potency & 34 & 2 & 5 & 4.264 & 0.863 \\
\hline $\begin{array}{l}\text { Revenue of provincial } \\
\text { (in million Rupiah) }\end{array}$ & 34 & 240,000 & $40,359,999$ & $4,017,352$ & $7,490,972.104$ \\
\hline Number of Universities & 34 & 8 & 543 & 132.558 & 145.178 \\
\hline $\begin{array}{l}\text { Accountability level } \\
\text { (PWAL) (\%) }\end{array}$ & 34 & 0.200 & 1.000 & 0.633 & 0.223 \\
\hline
\end{tabular}

of amount was one to five. Finally, before the hypothesis tested. The following least squares (OLS) regression model (2) had tested and met with the assumptions of classical linear by using SPSS 21 statistical software (Ghozali, 2005).

Where:

$\mathrm{i}=$ the 34 provinces official websites.

PWAL $=$ the percentage of website accountability level.

$\mathrm{NP}=$ the natural logarithm of the number of people.

$\mathrm{ND}=$ the natural logarithm of the number of districts/cities.

MN = the natural logarithm of the number of media news.

$\mathrm{EP}=$ the amount of economic potency (1 to 5 ).

$\mathrm{RP}=$ the revenue of provincial governments.

$\mathrm{NU}=$ the natural logarithm of the number of universities in provincial region.

e $\quad=$ the error term.

Thus, the statistical results showed in the following tables:

\section{Results and Discussions}

Based on the descriptive information on Table I and II, the first research question answered. As shown, the average result of the level of accountability in the provincial's official website is $63 \%$. The score indicates that the Indonesia provincial governments have put a proper attention on the internet accountability issues for maintaining their social legitimacy. However, the accountability score in each the primary dimensions (organizational profile; public policies and implementation measures; expenditures; procurement; administrative efficiency) is not good at all. In fact, although the information related to government expenditure is high as got a mean of 4 from the range o to 5 . But, the information that related to public policies and implementation measures just got a mean of 3 from a range of o to 6. Moreover, more specific to the points of GRI standards (GRI, 2010), the score from the social and environmental indicators is still bad. As it can be seen, starting from PA2 (standard of sustainability), PA7 (social engagement with stakeholders), PA12 (economic, environmental, social expenditures), and PA14 (procurement of goods that have social and environmental certificates) which still have a mean of 0 . Thus, this result indicates that, as overall, the provincial governments still have no high intention to be more accountable in the social and environmental field on 
Table 3

OLS Regression Results

\begin{tabular}{|c|c|c|c|c|c|}
\hline \multirow[b]{2}{*}{ Variables } & \multirow[b]{2}{*}{ Predicted sign } & \multirow[b]{2}{*}{ Coefficients } & \multirow[b]{2}{*}{ t-statistics (sign.) } & \multicolumn{2}{|c|}{ Collinearity tests } \\
\hline & & & & Tolerance & VIF \\
\hline Constant & & 1.174 & $0.456(0.652)$ & & \\
\hline NP & + & 0.302 & $2.821(0.009)^{* *}$ & 0.812 & 2.246 \\
\hline ND & + & 0.259 & $1.945(0.043)^{* *}$ & 0.179 & 5.601 \\
\hline $\mathrm{MN}$ & + & 0.040 & 0.090 (0.929) & 0.609 & 1.642 \\
\hline EP & + & -0.025 & $-0.549(0.588)$ & 0.662 & 1.510 \\
\hline $\mathrm{RP}$ & + & -0.107 & $-1.508(0.144)$ & 0.130 & 7.719 \\
\hline NU & + & 0.040 & $0.352(0.728)$ & 0.175 & 3.296 \\
\hline Adjusted R²(\%) & $33 \cdot 5 \%$ & & & & \\
\hline F-Value (significance) & $3.372(0.011)$ & & & & \\
\hline$N$ & 34 & & & & \\
\hline
\end{tabular}

Notes: ** indicate significance at the 0.05 levels. The p-values are one-tailed for directional hypotheses and two-tailed otherwise. Variables definitions: $P W A L=$ the percentage of website accountability level; $N P=$ the natural logarithm of number of people; $N D=$ the natural logarithm of number of districts/cities; $M N=$ the natural logarithm of number of media news; $E P$ = the amount of economic potency (1 to 5); $R P=$ the revenue of provincial governments; $N U$ = the natural logarithm of number of universities in provincial region.

their official websites.

Furthermore, the OLS regression result in Table III used to test the hypothesizes of this research. The regression coefficient for NP and ND are positive and significant $(\mathrm{p}<0.05)$, which provides further support for Hia and $H 1 b$. In other words, it can be explained as more high the number of people and districts/cities in one province, the higher social pressure that felt by the provincial governments and it will lead to the more accountable them in their official websites for maintaining the government's legitimacy in this internet time. Also, the result is consistent with some studies in the website accountability field (Gandı'a \& Archidona, 2008; Greiling et al., 2015; Joseph et al., 2014). In addition, this study also offers more support for social legitimacy theory in the local government, specifically in Asia and developing country settings which are still limited to be studied (Joseph et al., 2014).

On the other hand, the regression coefficient for other independent variables is insignificance ( $p>0.05)$.
Several reasons then allegedly as the explanations such as; first, in Indonesia context, as shown in Table I and II, even the provincial governments have a high score for EP (the economic potency of provincial region) as it has a mean of 4 from range 0 to 5 . But the governments have not automatically increased the accountability level on their official websites. It may based on the fact showed that the higher economic exploitation in all economic potencies in line with the greater environmental disaster in provincial environment (WALHI, 2015)). So, the governments may doubt, if they are more accountable on their official websites, specifically in environment context. It may lead to the inhibition of the economic development in each economic potency by the social activist and people protest. As widely believed by the logic of capitalisteconomic development view that public's criticisms and protests are inhibiting the economic growth (Chiapello, Du Gay, \& Morgan, 2013; Friedland, Piven, \& Alford, 1977; White, 2003). In line with the previous explanations, the number of 
Table IV

Data of the media news in 2015-2016

\begin{tabular}{lcc}
\hline & & mean \\
\hline & The number of media news (2015 to 2016) & 273,52 \\
2 & Economic theme & 90,29 \\
3 & Social theme & 90,61 \\
& Environment theme & 92,61
\end{tabular}

Notes: The number of media news are gathered manually by counting the news in "google.com'

media news (MN) has also insignificance effect ( $p>0.05$ ) to the accountability level on the provincial governments' official websites. This empirical fact supports the claims that the Indonesia provincial governments still have the low level of attention in website-based accountability policy to facilitate the people voice. Especially, in the social and environmental contexts that are still not become their main concern (see table I) although the number of news is so high (see table IV). In addition, the second reason, the provincial governments in Indonesia still do not implement the scheme of legitimacy tactics (C. G. Deegan, 2007; Lanis \& Richardson, 2013; O'Donovan, 1999; Shahib \& Irwandi, 2016) in their official websites as well. So, the higher economic potency and the media news do not automatically affect the accountability level on the provincial official websites. In other words, the $\mathrm{H}_{2}$ and $\mathrm{H}_{3}$ rejected.

Moreover, in Indonesia provincial settings, the higher the provincial revenue (RP) is not automatically affecting the level of accountability on the provincial's official websites $(\mathrm{p}>$ 0.05). Thus, the $\mathrm{H}_{4}$ rejected. Based on the information of table I and II, with the mean of $63 \%$ in accountability level. There is a possibility that the creativity of government officer may participate in making the high level of website-based accountability. As the fact showed, there is still no a government standard in doing accountability reporting in the official websites (Carol A. Adams et al., 2014; Gandı'a \& Archidona, 2008; Greiling et al., 2015; Joseph et al., 2014; TiradoValencia et al., 2016) and there are many ways to build the low-cost official websites (Adler, Gent, \& Overmeyer, 1998; Lakhani \& Von Hippel, 2003). So, the empirical fact that shows the availability of governments funds does not have a direct effect to the websitebased accountability level in Indonesia provincial situations can be accepted and lead to add the additional insight in local government and governance literature. Next, the number of universities has also insignificant effect $(p>0.05)$ to the percentage of accountability level in provincial's official websites in Indonesia settings that lead to reject $\mathrm{H}_{5}$. This result is different with the previous studies that found the high universities number could give rise to the rising of internet literacy in the society (Buckingham, 2007; Eshet-Alkalai, 2004; Livingstone, 2004; Metzger et al., 2003). The different empirical facts between this study and previous studies may be due to different characteristics of the university in Indonesia and other countries, specifically for developed countries that become the primary research object in previous studies (Buckingham, 2007; Eshet-Alkalai, 2004; Livingstone, 2004; Metzger et al., 2003). In Indonesia context, although the university number is high as it can be seen from Table II. The equitable distribution of the campus number is still a big problem 
in Indonesia. Based on the ministry of higher education of Indonesia (DIKTI, 2016). Most of universities, in range of 200 to 500 campuses, are located in the developed and industrialized provinces such as East Java, Jakarta, Central Java, West Java, North Sumatera, and South Sulawesi. So the inequitable distribution of campus is enough to explain why the accountability level in the provincial official website is not linear with the high number of universities in Indonesia and developing country context.

\section{Conclusion}

Onthewhole, this studyadds additional insight to the growing literature related to the accountability activities in the local government settings. Specifically, in this internet era, where the people have made the internet as the primary source and a tool to get information, give suggestion and criticize the government. Thus, there are several significant contributions from this study that could be learned by the scholars, society, and the government in the future.

First, this study shows, in developing country like Indonesia, the provincial governments have focused on delivering their accountability to the society by using their official websites. It is in line with the progress of the times and the increasing of internet users in the society. This condition is a good sign for the Good Government Governance (GGG) and the development of democracy in Indonesia. Second, as this study found, although in overall, the provincial governments have a good intention to be more accountable in their official website, they still have no good desire to be more accountable in specific themes such as environmental and social themes. Whereas, both these things are also necessary to be reported to the society. As consequence of with around 50\% of all economic, social and environmental activities bounded to the public sector. Specifically, in the local governments, because the local governments are the key actors in the sustainability accountability program as they always face the environmental problems daily and directly (A Ball, 2007; Qian et al., 2011; Stiglitz, Sen, \& Fitossi, 2009). Thirdly, this study also found that the press news yet becomes the one of the major considerations in making website-based accountability reports. Specifically, based on the environment and social news themes. Thus, in the other words, the second and third findings of this research also give additional insight to the socio-legitimacy explanations in the local government in developing country setting.

Furthermore, this study has suggestions for policy-makers and the society as a whole. Firstly, the study suggests to the local governments to disclose more information on their official websites as the accountability actions to the community. Primarily, the social and environmental information that relates to the sustainability of the region and peoples' life. Secondly, to strengthen the democracy, the local governments should give more attention to the press news and the people or activist critiques on their official websites. For example, give a suggestion and critique account and also make the accountability data accessible in PDF format. So the society can easily access and provide an input point to the government activities.

Finally, a limitation of this paper is that this paper assumes, in this internet era, the local governments just use their official website for delivering the accountability report. This paper still does not examine the use of Facebook, Twitter, and Instagram as other official media that may be used as an accountability tool for the local governments. Hence, the future research 
will consider examining broader media that utilized by the local government for reporting the accountability activities in Indonesia or different context. Also to consider another effect that is thought to affect the accountability style of the local government to add the new insight into the accountability literature in this internet age.

\section{References}

Adams, C. A., \& Frost, G. R. (2006). Accessibility and functionality of the corporate web site: implications for sustainability reporting. Business Strategy and the Environment, 15(4), 275-287.

Adams, C. A., Muir, S., \& Hoque, Z. (2014). Measurement of sustainability performance in the public sector. Sustainability Accounting, Management and Policy Journal, 5(1), 46-47.

Adler, E. S., Gent, C.E., \& Overmeyer, C. B. (1998). The home style homepage: Legislator use of the World Wide Web for constituency contact. Legislative Studies Quarterly, 585595.

Ball, A. (2005). Environmental accounting and change in UK local government. Accounting, Auditing \& Accountability Journal, 18(3), 346-373.

Ball, A. (2007). Environmental accounting as workplace activism Critical Perspectives on Accounting, 18(7), 759-778.

Bertot, J. C., Jaeger, P. T., \& Grimes, J. M. (2012). Promoting transparency and accountability through ICTs, social media, and collaborative e-government. Transforming Government: People, Process and Policy, 6(1), 78-91.

BI. (2015). LAPORAN PEREKONOMIAN INDONESIA 2015. Jakarta: Bank Indonesia.
Bolívar, M. P. R. (2007). Evaluating corporate environmental reporting on the internet: the utility and resource industries in Spain. Business \& Society, 48(2), 179-205.

BPS. (2015). Statistical Yearbook of Indonesia 2015. Jakarta: Badan Pusat Statistik/BPS - Statistics Indonesia.

Brown, N., \& Deegan, C. (1998). The Public Disclosure of Environmental Performance Information: a test of Media Agenda Setting Theory and Legitimacy Theory. Accounting and Business Research, 16(4), 558581.

Buckingham, D. (2007). Digital Media Literacies: rethinking media education in the age of the Internet. Research in Comparative and International Education, 2(1), 4355.

Cappella, J. N., \& Jamieson, K. H. (1997). Spiral of cynicism: The press and the public good: Oxford University Press.

Cheung, A. B. L. (2011). NPM in Asian countries. In T. Christensen \& P. Lægreid (Eds.), The Ashgate research companion to new public management Farnham, England: Burlington, VT: Ashgate.

Chiapello, E., Du Gay, P., \& Morgan, G. (2013). Capitalism and its criticisms. New spirits of capitalism? Crises, justifications, and dynamics, 6081.

Christiaens, J. (1999). Financial accounting reform in Flemish municipalities: an empirical investigation. Financial Accountability \& Management, 15(1), 21-40.

Coale, A. J., \& Hoover, E. M. (2015). Population growth and economic development: Princeton University Press.

Conrad, P. (1997). Public eyes and private 
genes: Historical frames, news constructions, and social problems. Social Problems, 44(2), 139-154.

Coupland, C. (2006). Corporate social and environmental responsibility in web-based reports: Currency in the banking sector? Critical Perspectives on Accounting, 17(7), 865-881.

Deegan, C., \& Gordon, B. (1996). A study of the environmental practices of Australian corporations. Accounting and Business Research, 26(3), 187-189.

Deegan, C., Rankin, M., \& Tobin, J. (2002). An Examination of the corporate social and environmental disclosure of BHP from 19831997. Accounting, Auditing and Accountability Journal, 9(2), 5067.

Deegan, C. G. (2007). Financial accounting theory. Australia: McGraw-Hill Irwin.

DIKTI. (2016). Data Perguruan Tinggi di Indonesia. Retrieved 25 December, 2016, from http://forlap. ristekdikti.go.id/perguruantinggi/ homegraphpt

Dowling, J., \& Pfeffer, J. (1975). Organizational legitimacy: Social values and organizational behavior. Pacific sociological review, 122136.

Eltantawy, N., \& Wiest, J. B. (2011). The Arab spring| Social media in the Egyptian revolution: reconsidering resource mobilization theory. International Journal of Communication, 5, 18.

Enikolopov, R., Petrova, M., \& Zhuravskaya, E. (2011). Media and political persuasion: Evidence from Russia. The American Economic Review, 101(7), 3253-3285.

Eshet-Alkalai, Y. (2004). Digital literacy: A conceptual framework for survival skills in the digital era. Journal of Educational Multimedia and Hypermedia, 13(1), 93.

Friedland, R., Piven, F. F., \& Alford, R. R. (1977). Political conflict, urban structure, and the fiscal crisis1. International Journal of Urban and Regional Research, 1(1 $\square$ 4), 447-471.

Gamerschlag, R., Moller, K., \& Verbeeten. (2010). Determinants of Voluntary CSR disclosure: Emperical Evidence from Germany. Review Management Science, 5(1), 233262.

Gandı'a, J. L., \& Archidona, M. C. (2008). Determinants of web site information by Spanish city councils. Online Information Review, 32(1), 35-57.

Ghozali, I. (2005). Aplikasi Analisis Multivariate dengan Program SPSS. Semarang: Badan Penerbit Universitas Diponegoro.

Graber, D. A. (2009). Mass media and American politics: Sage.

Gray, R., Kouhy, R., \& Lavers, S. (1995). Corporate Social and Enviromental Reporting: a Review of The Literature and a Longitudinal Study of UK Disclosure. Accounting, Auditing and Accountability Journal, 8(2), 47-77.

Greiling, D., Traxler, A. A., \& Stötzer, S. (2015). Sustainability reporting in the Austrian, German and Swiss publicsector.InternationalJournal of Public Sector Management, 28(4/5), 404-428.

GRI. (2010). GRI Reporting in Government Agencies: Global Reporting Initiative.

Groff, J. E., \& Pitman, M. K. (2004). Municipal financial reporting on the world wide web: a survey of financial data displayed on the official websites of the 100 largest US municipalities. The Journal of Government Financial 
Management, 53(2), 20.

Guillamón, D., Bastida, F., \& Benito, B. (2011). The determinants of local government's financial transparency. Local Government Studies, 37(4), 391-406.

Guthrie, \& Parker. (1989). Corporate social responsibility practice: a rebuttal of legitimacy theory. Accounting and Business Research, 19(1), 343-352.

Herman, E. S., \& Chomsky, N. (2010). Manufacturing consent: The political economy of the mass media: Random House.

Internet World Stats. (2016). Top 20 Countries with The Highest Number of Internet Users. Retrieved 25 December, 2016, from http://www. internetworldstats.com/top20.htm

Jose, A., \& Lee, S.-M. (2007). Environmental reporting of global corporations: A content analysis based on website disclosures. Journal of Business Ethics, 72(4), 307-321.

Joseph, C., Pilcher, R., \& Taplin, R. (2014). Malaysian local government internet sustainability reporting. Pacific Accounting Review, 26 (1/2), 75-93. doi: DOI 10.1108/ PAR-07-2013-0071

Kundu, A. (2011). Politics and economics of urban growth. Economic and Political Weekly, 10-12.

Lakhani, K. R., \& Von Hippel, E. (2003). How open source software works:"free" user-to-user assistance. Research policy, 32(6), 923-943.

Lanis, R., \& Richardson, G. (2013). Corporate Social Responsibility and Tax Aggresiveness: a Test of Legitimacy Theory. Accounting, Auditing \& Accountability Journal, 26(1), 75-100.

Laswad, F., Fisher, R., \& Oyelere, P. (2005). Determinants of voluntary internet financial reporting by local government authorities. Journal of Accounting and Public Policy, 24, 101-121.

LBH. (2016). Siaran Pers Advokasi Masyarakat Retrieved 20 May, 2016, from http://lbhmakassar. org/siaran-pers/

Light, P. (2011). Thickening government: Federal hierarchy and the diffusion of accountability: Brookings Institution Press.

Lipsky, M., \& Smith, S. R. (1989). Nonprofit organizations, government, and the welfare state. Political Science Quarterly, 104(4), 625-648.

Livingstone, S. (2004). Media literacy and the challenge of new information and communication technologies. The Communication Review, 7(1), 3-14.

Lodhia, S. K. (2006). Corporate perceptions of web-based environmental communication: an exploratory study into companies in the Australian minerals industry. Journal of Accounting \& Organizational Change, 2(1), 7488.

Metzger, M. J., Flanagin, A. J., \& Zwarun, L. (2003). College student Web use, perceptions of information credibility, and verification behavior. Computers \& Education, 41(3), 271-290.

Morison, J. (2000). Government $\square$ Voluntary Sector Compacts: Governance, Governmentality, and Civil Society. Journal of Law and Society, 27(1), 98-132.

Moura $\square$ Leite, R. C., \& Padgett, R. C. (2011). Historical background of corporate social responsibility. Social Responsibility Journal, 7(4), 528-539. doi: 10.1108/1747111111117511

Newman, J. (2001). Modernizing 
governance: New Labour, policy and society: Sage.

Norris, P. (2006). Did the media matter? Agenda-setting, persuasion and mobilization effects in the British general election campaign. British Politics, 1(2), 195-221.

O’Donovan, G. (1999). Managing legitimacy through increased corporate environmental reporting: an exploratory study. Interdisciplinary Environmental Review, 1(1), 63-99.

O'Donovan, G. (2002). Environmental disclosure in the annual report: extending the applicability and predictive power of legitimacy theory. Accounting, Auditing \& Accountability Journal

15(3), 344-371.

Olausson, U. (2010). Towards a European identity? The news media and the case of climate change. European Journal of Communication, 25(2), 138-152.

Osborne, D., \& Gaebler, T. (1992). Reinventing government: How the entrepreneurial spirit is transforming the public sector Reinventing government: How the entrepreneurial spirit is transforming the public sector.

Patten, D. (1992). "Intra-Industry Environmental Disclosures in Response to The Alaskan Oil Spill: a Note on Legitimacy Theory. Accounting,Organisations and Society, 7(1), 471-475.

Pierre, J. (2000). Debating governance: Authority, steering, and democracy: OUP Oxford.

Pilcher, R. (2011). Implementing IFRS in Local Government: Institutional Isomorphism as NPM Goes Mad? Local Government Studies, 37(4), 367-389.

Pina, V., Torres, L., \& Royo, S. (2009). E-government evolution in EU local governments: a comparative perspective. Online Information Review, 33(6), 1137-1168.

Pollach, I., Scharl, A., \& Gill, D. (2005). Solid Waste Management: Corporate and Third-Party Online Reporting. Paper presented at the 19th International Conference on Informatics for Environmental Protection (EnviroInfo-2005).

Purushothaman, M., Hancock, P., Brown, A., \& Scharl, A. (2006). Online environmental reporting practices of listed Singapore companies Paper presented at the The European Accounting Association Conference (EAA, Dublin, Ireland.

Qian, W., Burritt, R., \& Monroe, G. (2011). Environmental management accounting in local government. Accounting, Auditing \& Accountability Journal, 24(1), 93-128. doi: 10.1108/09513571111098072

Republika Online. (2015). DEMO SENIN TUNTUT LESTARIKAN HUTAN, CABUT IZIN PERUSAHAAN PEMBAKAR LAHAN. Retrieved 6 April, 2016, from http://politik.rmol. $\mathrm{co} / \mathrm{read} / 2015 / 09 / 27 / 218798 /$ Demo-Senin-Tuntut-LestarikanHutan,-Cabut-Izin-PerusahaanPembakar-Lahan-

Rosair, M., \& Taylor, D. W. (2000). The effects of participating parties, the public and size on government departments' accountability disclosures in annual reports. Accounting, Accountability \& Performance, 6(1), 77.

Rothstein, B. (2011). The quality of government: Corruption, social trust, and inequality in international perspective: University of Chicago Press.

Sanusi, A., Butler, B., \& Rola-Rubzen, M. F. (2013). Local Politics and 
Business in Indonesia: A Nonmarket Strategy Approach. Paper presented at the Provincial Governance Strengthening Programme supported by UNDP Indonesia, Unika Atmajaya, Jakarta.

Shahib, H. M., \& Irwandi, S. A. (2016). Violation regulation of financial services authority (FSA), financial performance, and corporate social responsibility disclosure. Journal of Economics, Business, and Accountancy Ventura, 19(1), 141154. doi: 10.14414/jebav.v19i1.533

Stiglitz, J. E., Sen, A., \& Fitossi, J.P. (2009). Commission on The Measurement of Economic Performance and Social Progress Report-2009. France: Commission on The Measurement of Economic Performance and Social ProgressFrance.

Tirado-Valencia, P., Rodero-Cosano, M. L., Ruiz-Lozano, M., \& RiosBerjillos, A. (2016). Online sustainability information in European local governments: An explicative model to improve transparency. Online Information Review, 4O(3), 400-415.

Torres, L., Pina, V., \& Royo, S. (2005). E-government and the transformation of public administrations in $\mathrm{EU}$ countries: beyond NPM or just a second wave of reforms? Online Information Review, 29(5), 531-553.

Tyler, T. R. (2006). Psychological perspectives on legitimacy and legitimation. Annu. Rev. Psychol., $57,375-400$.
Waddock, S. (2008). Building a new institutional infrastructure for corporate responsibility. Academy of Management Perspectives, -(-), $87-108$

Waisbord, S. R. (2013). Watchdog journalism in South America: News, accountability, and democracy: Columbia University Press.

WALHI. (2015). Tinjauan Lingkungan Hidup 2015 Wahana lingkungan Hidup Indonesia (2015 ed.). Jakarta: Wahana Lingkungan Hidup Indonesia (WALHI).

White, R. (2003). Environmental issues and the criminological imagination. Theoretical Criminology, 7(4), 483-506.

Williams, B., Wilmshurst, T., \& Clift, R. (2011). Sustainability reporting by local government in Australia: Current and future prospects. Accounting Forum, 35, 176-186.

Wilmshurst, T., \& Frost, G. R. (2000). Corporate Enviromental Reporting: a Test of Legitimacy Theory. Accounting, Auditing \& Accountability Journal, 13(1), 1026.

World-Bank. (2012). Doing Business in Indonesia 2012. Washington DC: World-Bank.

World Resources Institute. (2015). With Latest Fires Crisis, Indonesia Surpasses Russia as World's Fourth-Largest Emitter. Retrieved 6 April, 2016, from http://www. wri.org/blog/2015/10/latestfires-crisis-indonesia-surpassesrussia-world\%E2\%80\%99s-fourthlargest-emitter 